\title{
Baron Guillaume Dupuytren: when brilliance combats professionalism.
}

\author{
Sean M. Devitt, MD \\ Thomas Jefferson University \\ Charles J. Yeo, MD \\ Thomas Jefferson University \\ Pinckney J. Maxwell, IV, MD \\ Medical University of South Carolina, Charleston
}

Follow this and additional works at: https://jdc.jefferson.edu/gibbonsocietyprofiles

Part of the History of Science, Technology, and Medicine Commons, and the Surgery Commons Let us know how access to this document benefits you

\section{Recommended Citation}

Devitt, MD, Sean M.; Yeo, MD, Charles J.; and Maxwell, IV, MD, Pinckney J., "Baron Guillaume Dupuytren: when brilliance combats professionalism." (2012). Department of Surgery Gibbon Society Historical Profiles. Paper 40.

https://jdc.jefferson.edu/gibbonsocietyprofiles/40

This Article is brought to you for free and open access by the Jefferson Digital Commons. The Jefferson Digital Commons is a service of Thomas Jefferson University's Center for Teaching and Learning (CTL). The Commons is a showcase for Jefferson books and journals, peer-reviewed scholarly publications, unique historical collections from the University archives, and teaching tools. The Jefferson Digital Commons allows researchers and interested readers anywhere in the world to learn about and keep up to date with Jefferson scholarship. This article has been accepted for inclusion in Department of Surgery Gibbon Society Historical Profiles by an authorized administrator of the Jefferson Digital Commons. For more information, please contact: JeffersonDigitalCommons@jefferson.edu. 


\title{
Baron Guillaume Dupuytren: When Buricall Leaders Combats Professionalism
}

SEAN M. DEVITT, M.D., ${ }^{*}$ CHARLES J. YEO, M.D., ${ }^{*}$ PINCKNEY J. MAXWELL IV, M.D.†

\author{
From the *Department of Surgery, Jefferson Medical College of Thomas Jefferson University, Philadelphia, \\ Pennsylvania; and the TMedical University of South Carolina, Charleston, South Carolina
}

B aron Guilluame Dupuytren was a French anatomist and surgeon who practiced during the 1800 s and is considered by some to be the most brilliant and gifted surgeons of his time. His contributions to the field of surgery are quite extensive, yet his eccentric personality and attitude toward his colleagues, students, and patients raises a very interesting question: could Dr. Dupuytren (Fig. 1) and his many contributions to the field of surgery have thrived in today's era of professionalism? The concept of professionalism is emphasized to medical students starting from day one of their medical training. How would Dr. Dupuytren, an esteemed anatomist, react to the idea that students are introduced to the idea of professionalism before entering the cadaver laboratory?

Dr. Dupuytren was born October 5, 1777, in PierreBuffiere, a small village in central France where his father practiced as an impoverished lawyer. Although Dr. Dupuytren originally intended to join the army, the influence of his father and other surgeons in the family led Dupuytren to pursue his medical studies in Paris in 1793. The next 2 years of desolation and hunger may have contributed to what would become his demanding and demeaning personality later in life. He spent his days in the anatomy laboratory and his nights studying using the fat from the cadavers to make oil for his lamp. ${ }^{1}$

After becoming a Doctor of Medicine in 1803, he quickly rose in the ranks of surgery in Paris and became Chief Surgeon at the Hotel Dieu Hospital (Fig. 2) in 1815 at the age of 38 years, creating many enemies along the way. ${ }^{2}$ Although it is said that Dr. Dupuytren was the hardest working surgeon who tirelessly strove for perfection at all times, many also note that he often took credit for the work of his colleagues and was known to plagiarize with regularity. While teaching a course on pathology at L'Ecole de Santa, his two assistants were Pierre Bayle and Rene Laennec. The trio eventually parted ways on bad terms when Dr. Laennec

Address correspondence and reprint requests to Pinckney $\mathrm{J}$. Maxwell IV, M.D., Assistant Professor of Surgery, Colon and Rectal Surgery, Medical University of South Carolina, 25 Courtenay Drive, Suite 7100A, Charleston, SC 29425. E-mail: maxwellpj@musc.edu. refused to work with Dr. Dupuytren, because he felt that Dr. Dupuytren was taking the credit for Dr. Bayle's work.

Dr. Dupuytren was an arrogant genius who is known for many sayings including "Je me suis trompe quelques fois, mais je crois m'etre trompe moins que les autres" ("I made some mistakes, but I think less than the others") and "rien n'est tant a redouter pour un home que la mediocrite" ("nothing save mediocrity is to be feared"). ${ }^{1}$ One would think his pompous attitude would lead to a life of isolation, yet when Dr. Dupuytren was on the wards nothing could have been further from the truth. His brilliance was recognized by those in the medical community and his peers, and medical students would come from hundreds of miles away to hear the expert lecture (Fig. 3).

Although his peers and his students were able to look past his unprofessional behavior, his controversial actions toward his patients may have led Dr. Dupuytren

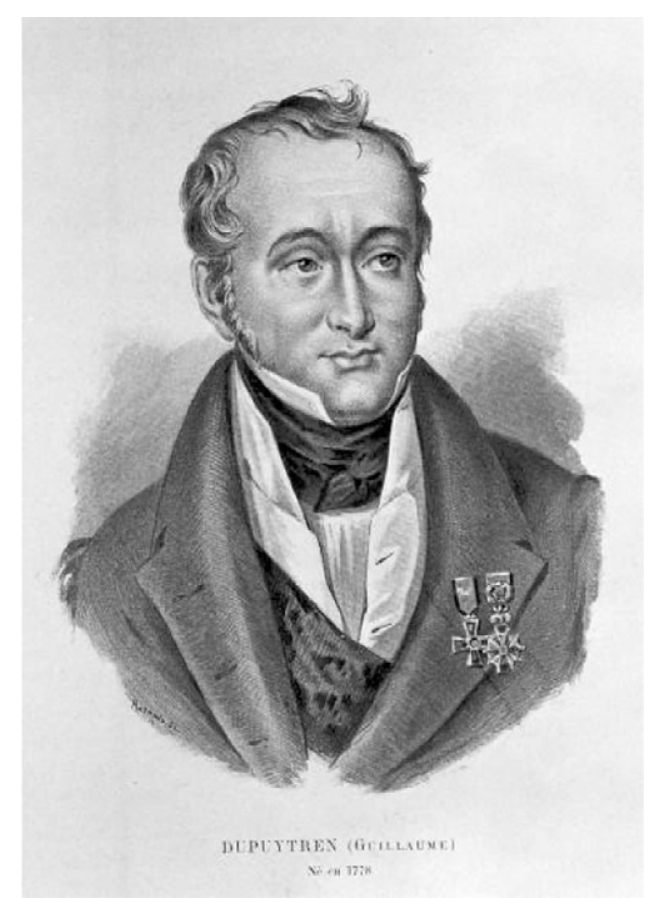

FIG. 1. Lithograph of Guillaume Dupuytren. Reprinted from "Centenaire de la faculte de medecine de Paris" by A. Corlieu. 


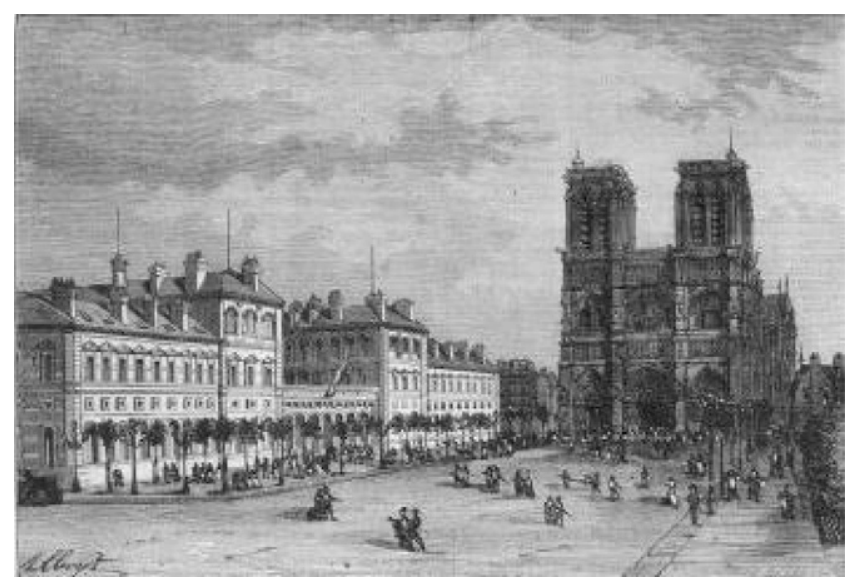

FIG. 2. Hotel Dieu in Paris, France, where Dupuytren would serve as Chief of Surgery for over 20 years. Aspergillus Newsletter page. Fungal Research Trust web site. Available at: www.aspergillus.org.uk/ updates/NewsletterOctober2009.html. Accessed October 15, 2009.

\section{CLINICAL LECTURES ON SURGERY,}

DELIVERED AT HOTEL DIEU, IN 1832,

By

BARON DUPUYTREN.

POBLIBHED BY AN ABBOOIATION OP PEYBIOIAKB.

TRANSLATED FROM THE FRENCH,

By

\section{A. SIDNEY DOANE, A.M., M. D.}

FIG. 3. Collected edition of Dr. Dupuytren lectures at the Hotel Dieu. Dupuytren BG. Clinical Lectures on Surgery: Delivered at Hotel Dieu, in 1832. Boston, MA: Carter, Hender, \& Co Publishers; 1833:8.

into trouble in modern times. Historic accounts provide two vastly different pictures of the same man, possibly confounded by the sources of information. On one side, it is accounted that Dr. Dupuytren was rude to his patients, often screaming at them and forcing them to their knees to speak to him. It is hypothesized that this maniacal portrait of the physician was painted by his colleagues with personal vendettas against him. On the other side, Dr. Dupuytren is regarded as being friendly and empathetic toward his patients, especially children and the less fortunate, stemming from his

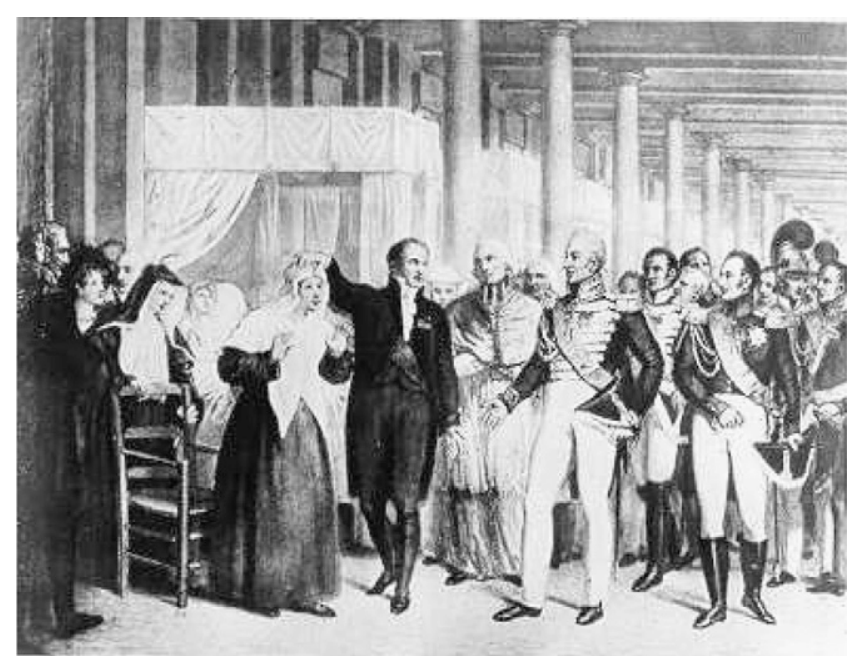

FIG. 4. Dr. Dupuytren presenting a patient to Charles X; located in the Musee Carnavalet in Paris, France. Downloaded from clendening.kumc.edu/dc/rm/19_157p1/jpg. Accessed October 15, 2009.

humble beginnings. Considering that he became one of the most successful and wealthy surgeons of his time, even offering Charles X of France (Fig. 4) a million francs when he was dethroned and bankrupt, it is most likely that he was a combination of a talented surgeon who demanded respect with an astute clinician who knew how to gain the respect and trust of his patients. ${ }^{1}$

During the middle of a lecture in 1833, Dr. Dupuytren suffered from a stroke that would forever change his life. Consistent with his relentless personality, Dr. Dupuytren finished the lecture. He attempted to retain his position but retired from the Hotel Dieu in 1834. He later died in 1835 from a lung empyema resulting from tuberculosis. ${ }^{3}$ When the most renowned surgeons of the time were deciding whether to drain the empyema, Dr. Dupuytren felt it was better to die from the disease than from the operation. Ironically, one of the greatest surgeons of the time who possibly performed more cases than any surgeon of the era had always wished to die at the hands of God and forgo surgical intervention. The life and success of Guillaume Dupuytren raises many questions about professionalism in the field of surgery today.

\section{REFERENCES}

1. Baron Guillaume Dupuytren. Whonamedit? A dictionary of medical eponyms web site. Available at: www.whonamedit.com/ doctor.cfm/1104.html. Accessed October 15, 2009.

2. Guillaume Dupuytren biography. Available at: www.faqs.org/ health/bios/2/Guillaume-Dupuytren.html. Accessed October 15, 2009.

3. Wylock P. The life and time of Guillaume Dupuytren. Can J Surg 1989;32:473-7. 